\title{
URGENSI MAINTAINABILITY SOFTWARE E-SPT DAN FAKTOR-FAKTOR YANG BERPENGARUH TERHADAP ALOKASI PENERIMAAN PAJAK PENGHASILAN (PPH) PASAL 25 BADAN DI KPP MADYA MALANG - JAWA TIMUR
}

\author{
AGUS RAHMAN ALAMSYAH \\ ZAINUL MUCHLAS \\ DOSEN STIE ASIA MALANG
}

\begin{abstract}
ABSTRAKSI
Penelitian ini bertujuan untuk mengetahui urgensi maintainability software e-SPT dan faktorfaktor yang berpengaruh terhadap alokasi penerimaan Pajak Penghasilan (PPh) Pasal 25 Badan, dasar pemilihan Pajak Penghasilan (PPh) Pasal 25 Badan karena total penerimaan pajak tertinggi dari semua kompenen pajak berasal dari penghasilan (PPh) dan ditemukan bahwa pemasukan dari penerimaan PPh Pasal 25 Badan merupakan jenis pajak penghasilan yang tertinggi diantara pajak penghasilan lainnya, selain itu untuk memaintenance sumber pemasukan tersebut maka Direktorat Jenderal Pajak (Dirjen Pajak) sebagai salah satu institusi pemerintah menerapkan sistem informasi perpajakan untuk kemudahan dan efektivitas kelancaran aktivitas penerimaan negara dari sektor pajak khususnya Pajak Penghasilan (PPh). Berdasarkan hasil penelitian maka dapat ditarik kesimpulan bahwa Urgensi Maintainability Software e-SPT, Surat Ketetapan Pajak, dan Kepatuhan Wajib Pajak berpengaruh secara positif dan mampu meningkatkan Penerimaan PPh Pasal 25 di KPP Madya Malang - Jawa Timur, sedangkan Jumlah Wajib Pajak berdampak negatif terhadap kenaikan Penerimaan PPh Pasal 25 di KPP Madya Malang - Jawa Timur.
\end{abstract}

Keywords: urgensi maintainability software e-SPT, Pajak Penghasilan (PPh) Pasal 25 Badan

\section{PENDAHULUAN}

Pajak sebagai sumber penerimaan yang potensial, pemerintah semaksimal mungkin berupaya untuk meningkatkan dan mengoptimalkan penerimaan pajak, upaya yang dilakukan pemerintah ini terlihat pada jumlah penerimaan pajak dalam Anggaran Pendapatan dan Belanja Negara (APBN) yang selalu meningkat dari tahun ke tahun, seperti terlihat dari tahun 2012 sampai dengan 2014, dimana pada tahun 2012 jumlah penerimaan pajak sebesar Rp. 139.870, 15 milyar dan merupakan 18,32\% dari jumlah keseluruhan Anggaran Pendapatan dan Belanja Negara (APBN), pada tahun 2013 jumlah penerimaannya meningkat sebesar Rp. 165.051,85 milyar dan merupakan 18,72 \% dari jumlah keseluruhan Anggaran Pendapatan dan Belanja Negara (APBN), kemudian pada tahun 2014 penerimaan pajak memberikan kontribusi sebesar 25,84\% terhadap jumlah keseluruhan PDB dengan nilai sebesar Rp. 269.325,99 milyar.

Berdasarkan data Direktorat Jenderal (Dirjen) Pajak tahun 2014, penyumbang utama penerimaan perpajakan $(19,91 \%)$ adalah penerimaan pajak penghasilan $(\mathrm{PPh})$, yaitu pajak yang dikenakan atas penghasilan yang merupakan tambahan kemampuan ekonomis yang diterima atau diperoleh wajib pajak, baik yang berasal dari Indonesia maupun dari luar Indonesia, yang dapat dipakai untuk konsumsi atau untuk menambah kekayaan wajib pajak (WP) yang bersangkutan. Realisasi penerimaan PPh migas mencapai Rp. 12.776,29 milyar dan penerimaan PPh nonmigas Rp. 73.027,21 milyar. Penerimaan $\mathrm{PPh}$ mengalami peningkatan yang cukup signifikan dalam periode waktu 2012 sampai dengan 2014, yaitu dari 16,46\% terhadap Anggaran Pendapatan dan Belanja Negara (APBN) dalam tahun 2012 menjadi $27.84 \%$ dalam tahun 2014. Dalam tahun 2014, penerimaan $\mathrm{PPh}$ mencapai Rp. 1,042,285.22 triliun, yang berarti $\mathrm{Rp} 885,026.62$ miliyar atau $84,91 \%$ lebih tinggi dari penerimaannya dalam tahun 2013. Peningkatan kinerja tersebut, utamanya bersumber dari penerimaan $\mathrm{PPh}$ non migas yang rasionya terhadap Anggaran Pendapatan dan Belanja Negara (APBN) meningkat dari $19,08 \%$ dalam tahun 2012 menjadi 19,91 \% dalam tahun 2013 dan menjadi $27.84 \%$ dalam tahun 2014. Berikut tabel data penerimaan Pajak Penghasilan $(\mathrm{PPh})$ di Indonesia Tahun 2012-2014:

Tabel 1.Realisasi Penerimaan Pajak Penghasilan (PPh) di Indonesia Tahun 2012-2014 (Dalam Milyar) 


\begin{tabular}{|c|c|c|c|c|c|c|}
\hline \multirow[t]{2}{*}{ No. } & \multirow[t]{2}{*}{ Jenis Pajak } & \multicolumn{3}{|c|}{ Realisasi } & \multirow{2}{*}{\begin{tabular}{|c|} 
Pertumbuhan \\
$2013(\%)$
\end{tabular}} & \multirow{2}{*}{\begin{tabular}{|c|} 
Pertumbuhthan \\
2014 $\left(0_{0}^{\circ}\right)$
\end{tabular}} \\
\hline & & 2012 & 2013 & 2014 & & \\
\hline (1) & (2) & (3) & (t) & (5) & $\begin{array}{c}(6)= \\
(+3) 3 \times 1000\end{array}$ & $\begin{array}{c}(7)= \\
(5-4)+4100 \%\end{array}$ \\
\hline 1. & PPh Psl 21 & $18,951,83$ & $25,586,64$ & $90.130,28$ & $35 \%$ & $252.26 \%$ \\
\hline 2. & $\mathrm{PPh} \operatorname{Ps} 22$ & $1.059,45$ & $1.408,46$ & $6.834,03$ & $32,94 \%$ & $385,21 \%$ \\
\hline 3. & PPh Ps/ 22 Impou" & 8333,82 & $11.431,99$ & $36.331,69$ & $37,18 \%$ & $217,81 \%$ \\
\hline 4. & $\mathrm{PPh} P \mathrm{Pl} 23$ & $4.822,92$ & $6.420,11$ & $22.206,45$ & $33,17 \%$ & $245,89 \%$ \\
\hline 5. & PPh Psl 25290 OP & $1.766,97$ & $2.032,14$ & $4.384,02$ & $15,01 \%$ & $115,73 \%$ \\
\hline 6. & PPh Psl 25/29 Badan & $31.285,09$ & $67,081,21$ & $155,066,4^{\circ}$ & $11+42 \%$ & $131,16 \%$ \\
\hline 7. & PPhPsl 26 & $4.948,01$ & $7.547,48$ & $31.100,12$ & $52,5 \% \%$ & $312,06 \%$ \\
\hline 8. & PPh Final & $13.872,11$ & $18.460,50$ & $71.565,73$ & $33,08 \%$ & $287,67 \%$ \\
\hline 9. & PPh Non Migas Laiminya & 5,94 & 7,62 & 37,80 & $37,35 \%$ & $396,06 \%$ \\
\hline
\end{tabular}

Sumber: Direktorat Jenderal Pajak (www.Pajak.go.id)

Berdasarkan tabel 1.1 diatas yang disajikan merupakan data jumlah penerimaan $\mathrm{PPh}$ untuk Indonesia secara keseluruhan. Dapat dilihat penerimaan pajak penghasilan $(\mathrm{PPh})$ tertinggi yaitu pemasukan dari penerimaan $\mathrm{PPh}$ Pasal 25 Badan, sehingga untuk me-maintenance sumber pemasukan tersebut maka Direktorat Jenderal Pajak (Dirjen Pajak) sebagai salah satu institusi pemerintah menerapkan sistem informasi perpajakan untuk kemudahan dan efektivitas kelancaran aktivitas penerimaan negara dari sektor pajak khususnya Pajak Penghasilan $(\mathrm{PPh})$. Dirjen Pajak berusaha untuk selalu menyempurnakan pelayanan terhadap wajib pajak dalam rangka mencapai visinya yaitu menjadi institusi pemerintah penghimpun pajak untuk negara yang terbaik di wilayah Asia Tenggara. Salah satu pelayanan yang diberikan adalah dengan penerapan aplikasi e-SPT. Aplikasi e-SPT atau disebut dengan SPT elektronik merupakan aplikasi yang dibuat oleh Dirjen Pajak untuk digunakan oleh Wajib Pajak guna memberikan kemudahan dalam penyampaian SPT (surat pemberitahuan terhutang). Dalam penerapan aplikasi atau software e-SPT tersebut, pihak Dirjen Pajak melalui divisi IT selalu melakukan pemeliharaan terhadap software yang digunakan wajib pajak. Salah satu bentuk penyempurnaan tersebut adalah dengan dikeluarkannya PER-11/PJ/2013 tentang Perubahan atas Peraturan Direktur Jenderal Pajak Nomor PER-44/PJ/2010 tentang Bentuk, Isi, dan Tata Cara Pengisian serta Penyampaian Surat Pemberitahuan Masa Pajak Pertambahan Nilai (PPN). Selain itu diterbitkannya PER14/PJ/2013 tentang Bentuk, Isi dan Tata Cara Pengisian dan Penyampaian Surat Pemberitahuan Masa Pajak Penghasilan Pasal (PPh) serta Bantuk Bukti Pemotongan
Pajak Penghasilan

(PPh)

(www.pajak.go.id)

Berdasarkan uraian di atas maka urgensi maintainability software e-SPT menjadi prioritas media yang efektif dalam memberikan kemudahan dalam penyampaian SPT (surat pemberitahuan terhutang) yang berisi perhitungan, pelaporan dan pembayaran pajak, akan tetapi aplikasi software e-SPT tidak akan berarti jika tidak ada pengingkatan jumlah wajib pajak, kepatuhan wajib pajak badan dan tanpa adanya penerbitan surat ketetapan pajak (SKP) sebagai dasar ketetapan pembayaran pajak oleh para wajib pajak. Untuk itu maka peneliti tertarik melakukan penelitian dengan judul "Urgensi Maintainability Software e-SPT dan Faktor-faktor yang Berpengaruh terhadap Alokasi Penerimaan Pajak Penghasilan (PPh) Pasal 25 Badan di KPP Madya Malang - Jawa Timur".

\section{Rumusan Masalah}

Berdasarkan latar belakang yang telah diuraikan di atas, adapun perumusan masalah yang dikemukakan dalam penulisan penelitian ini adalah:
1. Apakah urgensi maintainability
Software e-SPT berpengaruh terhadap peningkatan penerimaan Pajak Penghasilan (PPh) Pasal 25 Badan di KPP Madya Malang?
2. Faktor-faktor apakah yang
mempengaruhi peningkatan penerimaan Pajak Penghasilan $(\mathrm{PPh})$ Pasal 25 Badan di KPP Madya Malang?

\section{TINJAUAN PUSTAKA \\ Urgensi Maintainability e-SPT}

Menurut Perkasa, Shanda (2014), maintainability merupakan salah satu karakteristik penting dalam menentukan berkualitas atau tidaknya suatu sistem atau software. Maintainability adalah kemampuan software atau sistem untuk dapat dimodifikasi yaitu dilakukan koreksi atau perbaikan, adaptasi serta perbaikan. Sebuah software setelah berhasil diciptakan dan diterapkan harus dapat dilakukan proses kekinian atau update sesuai dengan perkemabngan dan dinamika yang berjalan di dalam ataupun di luar organisasi atau perusahaan. Maintainability suatu software memiliki sub karakteristik yang meliputi:

1. Analyzability, yaitu kemudahan untuk melakukan analisis terhadap penyebab terjadinya kesalahan. 
2. Changeability, yaitu kemudahan untuk melakukan perubahan atau koreksi terhadap software

3. Stability, yaitu kemudahan sistem untuk tetap stabil pada saat dioperasikan.

4. Testability, yaitu kemampuan sistem untuk dapat di test atau dilakukan uji coba setelah dilakukan perbaikan.

Menurut O-Brien dan Marakas

(2009) terdapat beberapa aktivitas dalam perawatan software, yaitu:

1. Correctice Maintenance, merupakan aktivitas yang dilakukan untuk menyelesaikan bugs dan logic error yang tidak terdeteksi pada saat implementasi periode percobaan. Prosentase biaya mencapai $21 \%$ dari total biaya perawatan yang dialikasikan.

2. Adaptive Maintenance, merupakan aktivitas perawatan yang dilakukan karena pertumbuhan atau perkembangan perangkat lunak atau perangkat keras sehingga memerlukan modifikasi atau penambahan fungsi yang lebih mutakhir untuk mengikuti perubahan lingkungan bisnis. Aktivitas ini membutuhkan $25 \%$ dari total biaya yang dialokasikan.

3. Perfective Maintenance, merupakan aktivitas perawatan yang dilakukan pada saat software telah ada dan dilakukan uji coba kemudian dilakukan peningkatan performa atau kemampuannya. Aktivitas ini membutuhkan porsi biaya yang paling besar yaitu mencapai $50 \%$ dari total biaya perawatan yang dialokasikan

4. Preventive Maintenance, merupakan aktivitas perawatan yang dilakukan untuk mengurangi risiko terjadinya kegagalan sistem atau menambah kapasitas dari daya guna sistem sebelumnya.

Urgensi Maintainability atau pentingnya proses pemeliharaan sistem ini dirasakan oleh orang-orang yang terlibat dalam aktivitas sistem informasi baik programmer maupun end user yang menggunakan sistem tersebut. Adapan urgensi atau alasan yang mendasari pentingnya maintainablity system dapat dipaparkan sebagai berikut :

1. Mampu meningkatkan produktivitas perusahaan, dengan melakukan pemeliharaan terhadap sistem atau software maka produktivitas perusahaan dapat ditingkatkan karena software yang digunakan dapat berjalan sesuai fungsinya tanpa ada hambatan. Sebaliknya sistem yang tidak berfungsi sebagaimana mestinya akibat kurangnya pemeliharaan atau proses maintenance dapat berakibat pada terhambatnya pekerjaan dan timbulnya kerugian bagi perusahaan atau organisasi.

2. Mampu meminimalisir biaya, pemeliharaan sistem memerlukan biaya yang besar namun apabila dibandingkan dengan biaya penggantian atau konversi dari sistem alam yang dinilai gagal ke sistem baru tentunya biaya yang dibutuhkan jauh lebih murah. Pembelian sistem yang baru berarti mengganti semua perangkat yang telah ada termasuk memberikan pelatihan ulang kepada operator atau pengguna.

3. Mampu memperbaiki kesalahan, dengan menerapkan pemeliharaan sistem yang berkelanjutan maka tingkat kesalah dalam penggunaan sistem dapat diminimalisir. Kesalahan yang mungkin terjadi dapat diperbaiki dengan menyediakan software yang terpercaya dan dapat diandalkan.

4. Mampu menjamin dan meningkatkan daya kerja sistem, pemeliharaan sistem secara berkala akan mampu menjamin kemampuan sistem kerja dengan lebih baik. Aktivitas ini dilakukan dengan cara melakukan peninjauan atau monitoring secara periodik terhadap sistem sehingga masalah yang mungkin timbul dapat segera terdeteksi dan segera dilakukan perbaikan.

5. Mampu menjaga kekinian sistem. Pemeliharan sistem akan mampu membuat sistem tangguh dan adaptif terhadap berbagai perubahan yang terjadi baik perubahan secaa internal maupun eksternal di lingkungan organisasi atau lingkungan bisnis. Proses update atau pemutakhiran sistem dilakukan melalui modifikasi dalam setiap komponen yang dibutuhkan sistem.

\section{Pengertian Pajak Penghasilan}

\section{Pengertian Pajak}

Menurut Djajadiningrat yang dikutip oleh Resmi dalam bukunya "Perpajakan Indonesia" (2012:2), Pajak adalah "Kewajiban menyerahkan sebagian kekayaan ke kas negara yang disebabkan 
suatu keadaan, kejadian, dan perbuatan yang memberikan kedudukan tertentu tetapi bukan sebagai hukuman menurut peraturan yang ditetapkan pemerintah serta dapat dipaksakan tetapi tak ada jasa timbal balik dari negara secara langsung, untuk memelihara kesejahteraan secara umum".

Pengertian Pajak menurut Undang-undang No. 6 Tahun 1983 sebagaimana telah diubah beberapa kali terakhir menjadi Undang-undang No.16 Tahun 2009 Pasal 1 angka (1) adalah "Kontribusi wajib kepada negara yang terutang oleh orang pribadi atau badan yang bersifat memaksa berdasarkan undangundang, dengan tidak mendapatkan imbalan secara langsung dan digunakan untuk keperluan negara bagi sebesar-besarnya kemakmuran rakyat".

\section{Pajak Penghasilan (PPh) Pasal 25}

Menurut Resmi (2012:337) pengertian dari PPh Pasal 25 adalah "angsuran PPh yang harus dibayar sendiri oleh Wajib Pajak untuk setiap bulan dalam tahun pajak berjalan".

Pembayaran oleh Wajib Pajak dalam tahun berjalan dapat dilakukan dengan cara:

a. Wajib Pajak membayar sendiri pajaknya melalui angsuran setiap bulan (PPh Pasal 25).

b. Melalui pemotongan/pemungut oleh pihak ketiga.

\section{Cara Menghitung Pajak Penghasilan (PPh) Pasal 25}

Besarnya PPh Pasal 25 adalah sebesar $\mathrm{PPh}$ terutang menurut Surat Pemberitahuan (SPT) PPh tahun lalu dikurangi pajak-pajak yang telah terbayar (PPh Pasal 21, 22, 23, 24) kemudian hasilnya dibagi 12 atau banyaknya bulan dalam bagian tahun pajak.

Cara penghitungan PPh Pasal 25 untuk Badan adalah:

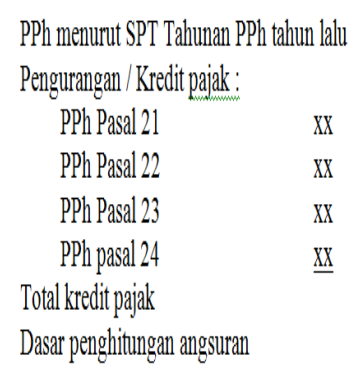

$\mathrm{XXX}$

Sehingga untuk menentukan Pajak Penghasilan $(\mathrm{PPh})$ Pasal 25 perbulan adalah:

$$
\text { Angsuran PPh Pasal } 25=\frac{\text { Dasar penghitungan angsuran }}{12}
$$

\section{Kerangka Konseptual}

Pada penelitian ini dijelaskan mengenai urgensi maintainability Software e-SPT dan faktor-faktor yang digunakan sebagai variabel ukuran peningkatan penerimaan Pajak Penghasilan (PPh) Pasal 25 Badan yang terdiri dari jumlah wajib pajak badan, kepatuhan wajib pajak badan dan penerbitan Surat Ketetapan Pajak (SKP). Adapun kerangka konseptualnya yang akan disajikan pada gambar dibawah ini :

\section{Gambar 1. Kerangka Konseptual}

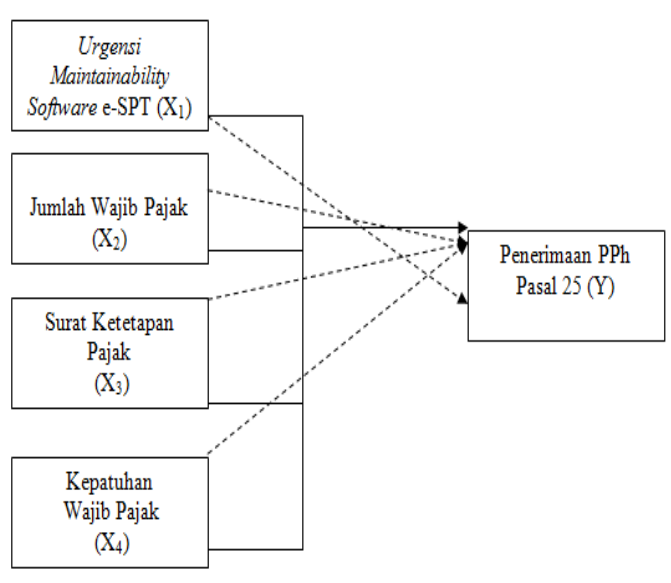

Sumber Data: Diolah Peneliti 
Keterangan :

Secara Simultan

Berpengaruh Secara Parsial

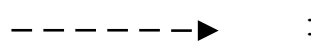

\section{TUJUAN, MANFAAT DAN LUARAN}

PENELITIAN

Tujuan dan Manfaat Penelitian

Tujuan Penelitian

Berdasarkan permasalah di atas, maka tujuan dari penelitian ini adalah untuk menguji dan memberikan bukti empiris dan praktis tentang urgensi maintainability Software e-SPT dan faktor-faktor yang mempengaruhi peningkatan Pajak Penghasilan (PPh) Pasal 25 Badan.

\section{Manfaat Penelitian}

a. Manfaat Teoritis

Memberikan kontribusi pemahaman tentang urgensi maintainability Software e-SPT dan faktor-faktor yang mempengaruhi peningkatan Pajak Penghasilan $(\mathrm{PPh})$ Pasal 25 Badan sesuai dengan peraturan perundangundangan perpajakan yang berlaku.

b. Manfaat Praktis

Memberikan gambaran dan wawasan mengenai urgensi maintainability Software e-SPT dan faktor-faktor yang mempengaruhi peningkatan Pajak Penghasilan $(\mathrm{PPh})$ Pasal 25 Badan serta sebagai bahan pertimbangan dan simulator pemutakhiran update software yang didukung dengan faktor-faktor yang mempengaruhi peningkatan Pajak Penghasilan ( $\mathrm{PPh})$ Pasal 25 Badan.

\section{Luaran yang Ditargetkan}

Luaran yang ditargetkan dari penelitian ini adalah:

1. Publikasi Ilmiah pada jurnal nasional atau lokal yang memiliki ISSN yaitu Jurnal Ilmiah Bisnis dan Ekonomi STIE ASIA Malang (JIBEKA)

2. Prosiding pada Seminar Ilmiah Nasional.

3. Pengayaan bahan ajar yang berkaitan dengan mata kuliah perpajakan, akuntansi dan manajemen.

\section{METODE PENELITIAN Tahapan Penelitian}

Tahapan dari penelitian ini dijabarkan sesuai dengan Creswell (2010), yang disajikan pada tabel 4.1 di bawah ini yaitu:

Tabel 2. Tahapan Penelitian

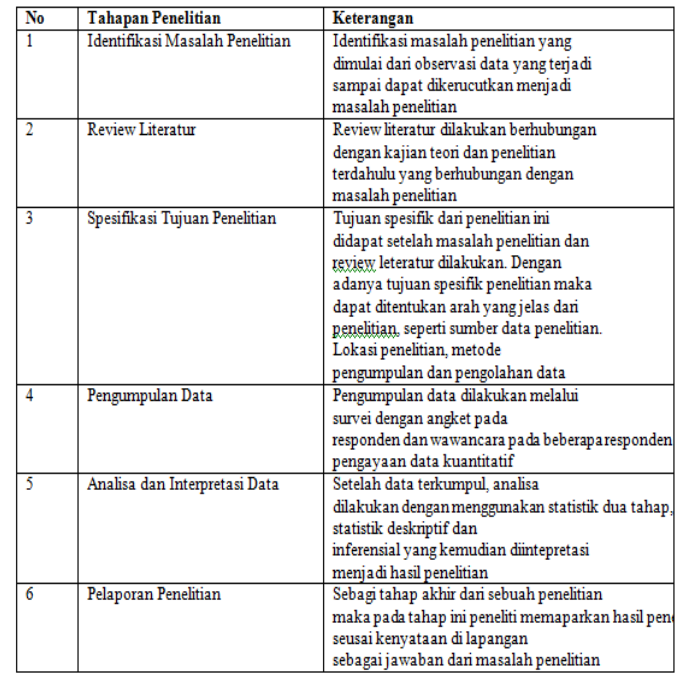

Jenis dan Sumber Data

1. Jenis Data

Jenis data yang digunakan dalam penelitian ini adalah data kuantitatif sebagai gambaran kondisi variabel bebas $(\mathrm{X})$ dengan variabel terikat $(\mathrm{Y})$.

2. Sumber Data

Sumber data dalam penelitian ini menggunakan data sekunder yang diperoleh dari KPP Malang Raya yang berupa jumlah wajib pajak, kepatuhan wajib pajak yang dapat dilihat dari SPT Masa badan yang dilaporkan, serta penerbitan surat ketetapan pajak (SKP) di KPP Madya Malang - Jawa Timur.

\section{Metode Pengumpulan Data}

Metode pengumpulan data yang digunakan dalam penelitian ini adalah:

1. Dokumentasi, dokumentasi dilakukan dengan cara mengumpulkan dengan mengamati, mencatat, dan mengkualifikasi data yang diperlukan langsung dari sumbernya. Data yang dimaksut diambil dari dokumen maupun sistem informasi direktorat jenderal pajak dari masing-masing devisi/seksi yang ada di KPP Madya Malang - Jawa Timur, misal: jumlah wajib pajak, SPT massa badan, serta penerimaan $\mathrm{PPh}$ pasal 25 badan terdapat di devisi/seksi pengolahan data dan informasi (PDI), sedangkan jumlah penerbitan surat ketetapan pajak (SKP) terdapat di devisi/seksi pelayanan

2. Observasi, data diperoleh melalui pengamatan terhadap urgensi 
maintainability software e-SPT yang digunakan oleh para wajib pajak.

\section{Variabel Penelitian}

Variabel penelitian terdiri dari 4 (empat) variabel bebas dan variabel terikat. Variabel terikat pada penelitian ini adalah Penerimaan Pajak Penghasilan (PPh) Pasal 25 Badan, sedangkan variabel bebasnya adalah Urgensi Maintainability Software eSPT, Jumlah Wajib Pajak, Surat Ketetapan Pajak, Kepatuhan Wajib Pajak Pajak.

\section{PEMBAHASAN}

Hasil Pengujian Validitas dan Reliabilitas

1. Pengujian Instrumen Penelitian

a. Uji Validitas

Validitas adalah suatu ukuran yang menunjukkan tingkat kevalidan atau kesahan suatu instrument (Arikunto, 2006:168). Dari hasil perhitungan didapatkan hasil bahwa item pernyataan yang ada di dalam variabel penelitian dinyatakan valid. Hal itu dapat dilihat dengan menggunakan tingkat signifikan $\alpha=0,05 \%$ dan nilai sig.2-tailed $=0,000$. Karena nilai sig.2tailed $<\alpha$, dan $r$ hitung $>\mathrm{r}$ tabel maka item pernyataan dinyatakan valid. Apabila probabilitas signifikansi hasil korelasi lebih kecil dari 0,05 maka dinyatakan valid dan sebaliknya jika nilai signifikansi lebih besar dari 0,05 maka dinyatakan tidak valid.

b. Uji Reliabilitas

Reliabilitas menunjukkan konsistensi dan stabilitas dari sebuah skor atau skala pengukuran. Uji reliabilitas dimaksudkan untuk menunjukkan tentang sifat suatu alat ukur apakah cukup akurat, stabil atau konsisten dalam mengukur apa yang diinginkan. Dengan ketentuan jika nilai Cronbach Alpha $\geq 0,60$, maka item penyataan dinyatakan reliable. Dari hasil perhitungan reliabilitas item pernyataan yang ada di dalam variabel penelitian hasilnya adalah nilai Cronbach Alpha $\geq 0,60$ yang berarti semua item pernyataan yang ada dalam masing-masing variabel dinyatakan reliable sehingga dapat digunakan untuk analisis berikutnya.

\section{Pengujian Asumsi Klasik}

\section{a. Uji Normalitas}

Uji normalitas bertujuan untuk menguji apakah dalam model regresi, variabel pengganggu atau residual memiliki distribusi normal.
Kalau asumsi ini dilanggar maka uji statistic menjadi tidak valid untuk jumlah kecil (Ghozali, 2005).

Dalam penelitian ini uji normalitas secara statistik juga menggunakan alat analisis One Sample Kolmogorov-Smirnov.

Pedoman yang digunakan dalam pengambilan kesimpulan adalah sebagai berikut :

1) Jika nilai sig (2-tailed) $>0,05$ maka distribusi data normal

2) Jika nilai sig (2-tailed) $<0,05$ maka distribusi data tidak normal

Dari hasil pengujian normalitas terlihat nilai signifikan lebih besar dari 0,05 yaitu sebesar 0,107 maka hasil penelitian ini menyimpulkan data penelitian telah berdistribusi normal memenuhi asumsi normalitas.

\section{b. Uji Multikolonieritas}

Uji multikolonieritas bertujuan untuk menguji apakah model regresi ditemukan adanya korelasi antar variabel independen, maka uji jenis ini hanya diperuntukan untuk penelitian yang memiliki variabel independen lebih dari satu. Multikolonieritas dapat dilihat dengan menganalisis nilai VIF (Variance Inflation Factor). Suatu model regresi menunjukkan adanya multikolonieritas jika :

1) Nilai Tolerance $<0,10$, atau

2) Nilai VIF $>10$.

Model regresi yang baik seharusnya tidak terjadi korelasi antar variabel independen (Ghozali, 2005). Dari hasil uji multikolonieritas terlihat hasil perhitungan nilai Tolerance menunjukkan tidak ada variabel independen yang memiliki nilai Tolerance $<0,10$. Hasil hitungan. Variance Inflation Factor (VIF) juga menunjukkan hal yang sama, tidak ada satu variabel independen yang memiliki nilai VIF $>10$. Hasil menunjukkan nilai VIF berkisar 1,808 sampai dengan 2,316, sehingga tidak ditemukan adanya multikolonieritas. Dan nilai Tolerance yang diperoleh berkisar 0,432 sampai dengan 0,553 juga tidak menunjukkan tidak adanya multikolonieritas dimana nilai Tolerance semua variabel lebih besar dari 0,10. Jadi dapat disimpulkan bahwa tidak ada multikolonieritas antar variabel independen dalam model regresi.

\section{c. Uji Heteroskedastisitas}




\begin{abstract}
Heteroskedasitas adalah keadaan dimana dalam model regresi terjadi ketidaksamaan varian dari residual pada satu pengamatan ke pengamatan yang lain. Model regresi yang baik adalah model regresi yang tidak mengalami heteroskedasitas. Pada penelitian ini peneliti mendetekdi adanya heteroskedasitas dengan melihat pola titik-titik pada scatterplots regresi dengan memperhatikan bahwa:

1) apabila terdapat pola tertentu seperti titik-titik ada membentuk pola tertentu yang teratur (bergelombang, melebar, kemudian menyempit) maka terjadi heteroskedasitas.

2) jika tidak ada pola yang jelas seperti titik-titik menyebar diatas dan dibawah angka 0 pada sumbu Y tidak terjadi heteroskedasitas
\end{abstract}

\section{d. Uji Autokorelasi}

Autokorelasi adalah keadaan dimana pada model regresi ada korelasi antara residual pada periode $\mathrm{t}$ dengan residual pada periode sebelumnya $(\mathrm{t}-1)$. Model regresi yang baik adalah yang tidak terdapat masalah autokorelasi. Metode pengujian menggunakan uji Durbin-Watson (DW Test). Pengambilan keputusan pada uji Durbin- Watson adalah sebagai berikut:

1) $\mathrm{d}<\mathrm{dL}=$ terdapat autokorelasi positif

2) $\mathrm{dL}<\mathrm{d}<\mathrm{dU}=$ ragu-ragu

3) $\mathrm{dU}<\mathrm{d}<4-\mathrm{dU}=$ tidak terdapat autokorelasi

4) 4-dL $<\mathrm{d}=$ terdapat autokorelasi negatif

Dari pengujian autokorelasi dapat diketahui bahwa nilai d hitung adalah 2,080. Bila nilai $\mathrm{k}=4, \mathrm{n}$ adalah 100 dan tingkat signifikasi adalah 5\% maka dari Durbin Watson didapatkan nilai $\mathrm{dL}=1,5922$ dan $\mathrm{dU}=1,7582$. Dengan demikian berlaku kondisi dU < $\mathrm{d}<4$-dU $=1,7582<2,080<2,242$ yang menyatakan bahwa tidak terjadi autokorelasi.

\section{Pembahasan}

\section{a. Uji Analisis Regresi Berganda}

Setelah metode penelitian

dirumuskan langkah selanjutnya yaitu mengolah data untuk mendapatkan model regresi berganda.Analisis regresi berganda digunakan untuk mengetahui ada tidaknya pengaruh variabel bebas atau independen terhadap variabel terikat atau dependen. Hasil uji regresi berganda di lampiran, model persamaan regresi berganda sebagai berikut:

Penerimaan PPh Pasal $25=$ $9,020+0,576 X_{1}-0,006 X_{2}+0,101$ $\mathrm{X}_{3}+0,071 \mathrm{X}_{4}$

Keterangan $=$

$\mathrm{Y}=$ Penerimaan $\mathrm{PPh}$ Pasal 25

$\mathrm{X}_{1}=$ Urgensi Maintainability Software e-SPT

$\mathrm{X}_{2}=$ Jumlah Wajib Pajak

$\mathrm{X}_{3}=$ Surat Ketetapan Pajak

$\mathrm{X}_{4}=$ Kepatuhan Wajib Pajak

Interpretasi dari masing-masing variabel diatas ialah

1) konstanta $(\alpha)=9,020$

Nilai konstanta sebesar 9,020 menunjukan bahwa nilai Penerimaan PPh Pasal 25 adalah sebesar 9,020 apabila tidak ada pengaruh Urgensi Maintainability Software e-SPT, Jumlah Wajib Pajak, Surat Ketetapan, dan Kepatuhan Wajib Pajak.

2) $\quad \beta 1=0,576$

Hal ini menunjukan bahwa setiap penambahan $\quad 1 \% \quad$ Urgensi Maintainability Software e-SPT maka akan meningkatkan Penerimaan $\mathrm{PPh}$ Pasal 25 di KPP Madya Malang Jawa Timur sebesar 0,576\%.

3) $\quad \beta 2=-0,006$

Hal ini menunjukan bahwa setiap penambahan 1\% Jumlah Wajib Pajak maka akan menurunkan Penerimaan PPh Pasal 25 di KPP Madya Malang Jawa Timur sebesar $0,006 \%$.

4) $\quad \beta 3=0,101$

Hal ini menunjukan bahwa setiap penambahan $1 \%$ Surat Ketetapan Pajak maka akan meningkatkan Penerimaan $\mathrm{PPh}$ Pasal 25 di KPP Madya Malang - Jawa Timur sebesar $0,101 \%$.

5) $\quad \beta 4=0,071$

Hal ini menunjukan bahwa setiap penambahan $1 \%$ Kepatuhan Wajib Pajak maka akan meningkatkan Penerimaan $\mathrm{PPh}$ Pasal 25 di KPP Madya Malang - Jawa Timur sebesar $0,071 \%$.

\section{b. Uji Determinasi}

Digunakan untuk mengukur kemampuan model dalam menerangkan variabel-variabel independen. Nilai koefisien determinasi berkisar antara 0 sampai dengan 1. Maka semakin besar 
pengaruh variabel independen ke variabel dependen. Hasil uji koefisien determinasi $\left(\mathrm{R}^{2}\right)$, menunjukkan bahwa Adjustted $\mathrm{R}$ Square sebesar 0,522 atau $52,2 \%$ yang berarti bahwa empat variabel independen dapat menjelaskan variabel dependen sebesar 52,2 \%, dan sisanya (100\%$52,2 \%=47,8 \%$ ) dijelaskan oleh faktor lain yang tidak diajukan oleh penelitian ini.

\section{c. Uji F}

Berdasarkan Pada tabel 4.9 dari uji ANOVA atau uji $\mathrm{F}$ didapat nilai $\mathrm{F}$ hitung sebesar $28,034 \geq \mathrm{F}$ tabel 2,46 atau dengan probabilitas $0,000<$ tingkat signifikansi $\alpha=0.05$, yang berarti Ho ditolak dan Ha diterima. Sehingga dapat disimpulkan bahwa Urgensi Maintainability Software e-SPT, Jumlah Wajib Pajak, Surat Ketetapan dan Kepatuhan Wajib Pajak (variabel independent) secara bersama-sama berpengaruh terhadap Penerimaan $\mathrm{PPh}$ Pasal 25.

\section{d. Uji t}

Uji $t$ atau uji koefisiensi regresi secara parsial yang digunakan untuk mengetahui apakah secara parsial variabel independen berpengaruh secara signifikan atau tidak terhadap variabel dependen. Dalam hal ini untuk mengetahui secara parsial Urgensi Maintainability Software e-SPT, Jumlah Wajib Pajak, Surat Ketetapan Pajak dan Kepatuhan Wajib Pajak (variabel independen) secara bersama-sama berpengaruh terhadap Penerimaan $\mathrm{PPh}$ Pasal 25. Berdasarkan signifikasinya, apabila signifikasinya $<0,05$ maka Ho ditolak dan jika signifikasinya $>0,05$ maka Ho diterima.

1) Pengaruh Urgensi
Maintainability Software e-SPT terhadap Penerimaan $\mathrm{PPh}$ Pasal 25, bahwa nilai $\mathrm{t}$ hitung dari variabel Urgensi Maintainability Software e-SPT sebesar 6,011>t tabel 1,664 dengan tingkat signifikasi sebesar 0,000 yakni dibawah 0,05 . Dapat disimpulkan bahwa Urgensi Maintainability Software eSPT memiliki pengaruh terhadap Penerimaan PPh Pasal 25. Itu bermula dari antusiasme masyarakat KPP Madya Malang - Jawa Timur yang sering meminta untuk diadakan sosialisasi perpajakan di tempat mereka bekerja. Sehingga dapat menambah jumlah wajib pajak terdaftar.

2) Pengaruh Jumlah Wajib Pajak terhadap Penerimaan PPh Pasal 25, bahwa nilai t hitung dari variabel Jumlah Wajib Pajak sebesar 1,062>t tabel 1,664 dengan tingkat signifikasi sebesar 0,000 yakni dibawah 0,05. Dapat disimpulkan bahwa
Jumlah Wajib Pajak tidak berpengaruh terhadap Penerimaan PPh Pasal 25.

3) Pengaruh Surat Ketetapan Pajak terhadap Penerimaan PPh Pasal 25, bahwa nilai $t$ hitung dari variabel Surat Ketetapan Pajak sebesar 2,723<t tabel 1,664 dengan tingkat signifikasi sebesar 0,000 yakni dibawah 0,05. Dapat. Dapat disimpulkan bahwa Surat Ketetapan Pajak berpengaruh terhadap Penerimaan PPh Pasal 25.

4) Pengaruh Kepatuhan Wajib Pajak terhadap Penerimaan PPh Pasal 25, bahwa nilai $t$ hitung dari variabel Kepatuhan Wajib Pajak sebesar $2,006<\mathrm{t}$ tabel 1,664 dengan tingkat signifikasi sebesar 0,000 yakni dibawah 0,05. Dapat disimpulkan bahwa Kepatuhan Wajib Pajak berpengaruh terhadap Penerimaan $\mathrm{PPh}$ Pasal 25.

\section{PENUTUP}

Kesimpulan

Berdasarkan pembahasan yang telah diuraikan, maka dapat ditarik kesimpulan bahwa Urgensi Maintainability Software e-SPT, Surat Ketetapan Pajak, dan Kepatuhan Wajib Pajak dapat berpengaruh secara positif dan mampu meningkatkan Penerimaan PPh Pasal 25 di KPP Madya Malang - Jawa Timur, sedangkan Jumlah Wajib Pajak berdampak negatif terhadap kenaikan Penerimaan PPh Pasal 25 di KPP Madya Malang - Jawa Timur.

\section{Saran}

Berdasarkan hasil penelitian, maka diberikan beberapa saran sebagai berikut :

1. Penelitian selanjutnya diharapkan menggunakan variabel $\mathrm{PPh}$ pasal 21/26 dan PPN agar memiliki kontribusi hasil penelitian yang berbeda dengan hasil penelitian yang telah diperoleh.

2. Penelitian selanjutnya dapat digunakan pada wajib pajak badan dari sektor lainnya seperti perdagangan, manufaktur dan jasa sehingga dapat memberikan gambaran tentang kepatuhan wajib pajak secara keseluruhan dan untuk jenis pajak lainnya.

\section{DAFTAR PUSTAKA}

1. Ghozali, Imam. Prof., Dr. 2005. Aplikasi Analisis multivariate dengan Program SPSS. Edisi keempat. Semarang: Badan Penerbit Universitas Diponegoro.

2. O'Brien, James A. 2005. Pengantar Sistem Informasi: Perspektif Bisnis 
dan Manajerial. Edisi 12. Jakarta(ID): Salemba Empat.

3. Resmi, Siti. 2012. Perpajakan: Teori dan Kasus. Buku 2. Edisi 6. Penerbit Salemba Empat. Jakarta.

4. O'Brien, James A and GM Marakas. 2009. Management Information Systems. Global Edition $11^{\text {th }}$ edition. The McGraw-Hill Companies, Inc.
5. Perkassa, Shanda. 2014. RPL Tugas 10: Pemeliharaan, Jenis Pemeliharaan dan Manfaat Pemeliharaan Software.

6. Undang-undang No. 6 Tahun 1983.

7. Undang-undang No.16 Tahun 2009.

8. Direktorat Jenderal Pajak, www.Pajak.go.id 